$2^{\text {nd }}$ International Conference on Research in
BUSINESS, MANAGEMENT AND FINANCE

22-24 November, 2019

PARIS, FRANCE

\title{
Training System and Skills Development within Algerian Companies
}

\author{
Dr. Imane Tabet Derraz \\ High school of management Tlemcen Algéria.
}

\begin{abstract}
Business success is strongly associated with developing the skills of their employees. Companies are actually spending more and more money on employee training to improve their skills in changing laws, procedures, organizational change, or simply to improve or perform; this learning, this training brings us to a specific goal is to develop skills.

The central question is:" how to build a good training system that will help develop skills?" In this article, we will explain the training system established by Algerian companies as well their motivations and their enthusiasms to obtain their fixed objectives; indeed, the field study speaks about the type of training established in an echoes of (35) Algerian companies in the department of accounting and finance since accounting standardization IAS / IFRS, that is to say the application of the financial accounting system from 2011 to the present day.
\end{abstract}

Keywords: Training, skills, system, development, accounting, IAS/IFRS, management. 